\title{
Teacher Perceptions and Implementation of a Content- Area Literacy Professional Development Program
}

\author{
Osha Lynette Smith, EdD \\ Walden University, Minneapolis, Minnesota, United States \\ (iD) https://orcid.org/0000-0001-9369-7959

\section{Rebecca Robinson} \\ Indiana University of Pennsylvania, Indiana, Pennsylvania, United States \\ (iD) https://orcid.org/0000-0002-2748-0492
}

Contact: $\underline{\text { osha.smith@mail.waldenu.edu }}$

\begin{abstract}
The Common Core State Standards recommend that all educators equip students with the literacy skills needed for college and careers. The purpose of this qualitative case study was to examine middle-level content-area teachers' perspectives on a district-led literacy professional development program and their implementation of the literacy strategies they learned. The conceptual framework included Bruner's constructivist, Bandura's self-efficacy, and Knowles's andragogy theories. These theories informed the investigation of adult learners' perspectives regarding the way they learn and gain confidence in providing literacy instruction. Eleven English, math, science, and social studies teachers participated in the study through individual interviews. Data were also gathered via classroom observations and lesson plans. The findings of the study indicated that teachers did implement the literacy strategies following the professional development provided despite lacking perceived self-efficacy with these skills. Although teachers saw value in literacy, their perceptions of the professional development were affected by their commitment to content instruction, time constraints, the organization of the professional development, and a forced compliance district mandate.
\end{abstract}

Keywords: middle school; content-area literacy; literacy; professional development

Date Submitted: June 29, 2019 | Date Published: May 8, 2020

\section{Recommended Citation}

Smith, O. L., \& Robinson, R. (2020). Teacher perceptions and implementation of a content-area literacy professional development program. Journal of Educational Research and Practice, 10, 55-69.

https://doi.org/10.5590/JERAP.2020.10.1.04

\section{Introduction}

Policy makers, business leaders, and educators have determined that for students' future success, they will need to be able to read deeply, analyze what they have read, and then form cohesive arguments based on their reading (National Governors Association Center for Best Practices, Council of Chief State School Officers, 2010). This determination resulted in the implementation of the Common Core State Standards (International Reading Association Common Core State Standards Committee, 2012), bringing literacy across 
disciplines to the forefront as a national priority in $\mathrm{K}-12$ education. Success in all disciplines requires literacy skills in order to read, write, and speak about complex content.

Content-area literacy requires content-area teachers to be trained in literacy skills for their discipline as well as be confident in their ability to teach and evaluate students as they use these skills. Literacy professional development is effective when teachers are confident and alter their teaching to include the literacy skills they learn. This study used interviews, classroom observations, and lesson plan analysis to determine the impact of a large-scale literacy professional development initiative on content-area teachers' confidence and resultant incorporation of literacy skills into their classroom instruction.

\section{Literature Review}

The way that teachers perceive new initiatives, and their likelihood of changing their instruction based on new training, can be explained in relation to Bruner's constructivist theory, Bandura's self-efficacy theory, and Knowles's theory of andragogy. Consideration of teachers' beliefs, the unique nature of middle-level contentarea literacy, and previous findings on professional development implementation in schools were also used to explain the design and results of this study.

\section{Theoretical Framework}

As mentioned, three frameworks guided this research: Bruner's constructivist theory, Knowles's theory of andragogy, and Bandura's theory of perceived self-efficacy. In constructivist theory, Bruner (1960) posited that learners build meaning from new concepts dependent on their present knowledge and learn through active practice. In education, constructivism explains the way that learning happens because of active student involvement in a shared learning environment (Khanal, 2014). When applied to teacher's learning of literacy teaching strategies, constructivist theory suggests that professional development must be based on teachers' previous knowledge and teachers must actively engage in understanding and using those strategies.

The second theory, Knowles's theory of andragogy, outlines specific learning needs and recommended methods to teach adults (Culatta, 2013; Henschke, 2008). Because the study participants were adult learners, their needs and learning styles differed from those of the children they taught (see Henschke, 2008). Adult learners have varied educational experiences and a desire to quickly transfer learning to their practical lives (Akin, 2014; Henschke, 2008). When applying andragogy to professional development for teachers, classroom authority should be shared between the student and the teacher, which is not the case in pedagogical education practices (Akin, 2014). Additionally, there is a difference in the attitudes and actions of teachers who guide adult learners and those who teach young people (Akin, 2014). For instance, adults can manage many aspects of their lives, so they can take part in the planning of their own learning. Further, the adult learners' experience is the foundation for their educational pursuits (Akin, 2014; Bruner, 1960; Culatta, 2013), meaning the instructional material must have immediate relevance to their profession or personal life.

Based on these concepts from Knowles's theory of andragogy, facilitators of literacy training programs may find benefits in including teachers in the planning and facilitation of learning sessions. Professional development facilitators may consider the five assumptions of andragogy when planning and implementing teacher training sessions: 
- Adult learners have an autonomous self-concept and can manage their own learning.

- Adult learners have a lifetime of experiences that can be used as resources for learning.

- The learning needs of adult learners may need to change as social roles change.

- Adult learners are known to focus on the problem and want to immediately apply what they learn.

- Adult learners are internally motivated. (Merriam, 2001)

Additionally, adult learners want to feel that they are respected, accepted, supported, and seen as joint owners of their learning (Merriam, 2001).

The third theory that influenced this study was Bandura's theory of perceived self-efficacy. Bandura's (1977) work on self-efficacy has shown that people's behavior is influenced by how competent they perceive themselves to be in meeting an expectation. In learning new skills, the level of competence that a learner feels depends on the complexity of the task and the way it is presented (Zimmerman, 1995). In organizing professional development where it is expected that teaching behaviors will change, success may depend on the self-efficacy of the teachers participating. Bandura's self-efficacy model shows that self-efficacy is affected by the participants' previous accomplishments with similar tasks, modeling of the expected behavior, how persuasively it is presented, and whether there is an emotional drive (Bandura, 1977; Zimmerman, 1995). Taking these four areas into consideration in professional development initiatives are important to ensure that teachers feel confident in using the new content and skills in their teaching.

These theories can help explain the success or failure of professional development opportunities offered to teaching staff. At the middle school level, the success of a literacy professional development program can also be influenced by the middle school organization, teachers' beliefs about literacy, and the nature of professional development offered by school districts.

\section{Middle-Level Content-Area Literacy}

At the middle-school level, a shift occurs in the way that content is delivered to students. Although elementary teachers are traditionally trained to teach all subject areas, middle-level teachers are generally certified in one or two content areas. Their preparation, therefore, focuses more on becoming experts in a specific content area than on methods of instruction to promote cross-disciplinary instruction, including literacy (Carney \& Indrisano, 2013; Guthrie \& Klauda, 2012; Hurst \& Pearman, 2013). This difference in training has been shown to influence middle-level teachers' willingness to incorporate other content-area skills into their instruction (Reed, 2009). Though content-area teachers see literacy as important, they are often reluctant to incorporate these strategies into their instruction (Daisey, 2012; Graham et al., 2017; Reed, 2009).

\section{Teacher Beliefs and Literacy Professional Development}

Beliefs influence instruction and affect a teacher's willingness to embrace literacy instruction. For example, people's perspectives toward reading influence their ability to consider literacy practices and their desire to practice literacy behaviors (Summers, 1977). Considering teachers' beliefs, knowledge, and teaching practice when planning new initiatives has had a positive effect on an initiative's ability to influence change in instruction (Bullock, 2011; Hall-Kenyon \& Smith, 2013; Park, 2013). This positive effect may be explained by previous research indicating that teachers' perspectives are influential in grounding their instructional practices (Clary et al., 2012; Falk-Ross \& Evans, 2014; Parsons et al., 2013). Multiple researchers have found that teachers' perspectives are pliable, especially when young teachers fill gaps in knowledge between theory and practice related to literacy (Ajayi, 2011; Orr et al., 2014; Warren-Kring \& Warren, 2013). These understandings are important to consider when designing curriculum for teachers because the perception of the learner can define the challenge and motivation necessary to apply expectations to practice. 


\section{Professional Development}

Opportunities for teachers' professional growth are often provided by professional development initiatives offered by school districts. These initiatives have been studied to determine their effect on teachers' perspectives and practice. Research has demonstrated that to be most effective, the learner must experience self-guided learning in a free, open atmosphere (Akin, 2014; Culatta, 2013). The perceived relevance of a program by teachers has also been found to influence the teachers' acceptance of the program (Jones \& Dexter, 2014). Organization of the program and the communication skills of the instructor have also shown a positive effect on the success of professional development initiatives (Arab, 2015; Moreillon, 2016). Furthermore, teachers have gained the most benefit from training that was collaborative, extended over a prolonged period, and provided coaching (Murphy, 2015).

District-facilitated professional development often uses one of the following models to provide training to their teaching staff: coaching, job-embedded trainings, professional learning communities, or 1-day mass trainings (Cohen, 2015; Cronin, 2014; Goldring et al., 2012; Green et al., 2013; Murphy, 2015; Woods, 2014).

Positive improvement in teaching practices have been found with professional development that was job embedded, which allows teachers to implement new practices immediately through collaboration with other adults (Moreillon \& Ballard, 2012). Job-embedded professional development allows teachers to share best practices, compare theory to what happens in the classroom, discuss and implement new strategies, and then reflect on what works and what should be changed for future practice (Jordan \& Kaplan, 2014). Previous as well as current research suggests that collaborative relationships creates environments where teachers feel safe to take risks, improve professional practice, and learn new instructional strategies, thus raising selfefficacy (Butler et al., 2015; Woods, 2014). Additionally, coaching-based strategies have been found to offer an adaptive approach, adjusting to a teacher's knowledge and needs (Ning et al., 2018).

Consistent and ongoing collaborative learning is also evident in professional learning communities, which is another model that districts use for professional development. Teachers who work together are in an ideal position to realize their beliefs, reflect on instruction, and collaborate to initiate the needed reforms when implementing new initiatives (Dillon et al., 2015; Wardrip et al., 2015). In support of the practice of common planning time or professional learning communities, teachers have claimed that they appreciated having a voice in what initiatives are implemented and how (Butler et al., 2015).

In contrast to the other two methods, 1-day mass trainings have been found to be the least effective method for providing professional development that yields changes in teaching practice (Wei et al., 2009). These trainings are often ineffective because they lack interaction and do not consider nor adjust to the needs of the teachers (Matherson \& Windle, 2017)

\section{Method}

\section{Research Questions}

The purpose of this qualitative case study was to explore middle-level content-area teachers' perspectives on their ability to teach literacy while engaged in a professional development program that focused on this topic. The research used interviews, lesson plan reviews, and classroom observations. The study sought to answer the following research questions: 
Research Question 1: Does the current literacy professional development engage middle-level teachers?

Research Question 2: How capable do middle-level content-area teachers feel regarding teaching literacy to their students following the professional development?

Research Question 3: To what extent do middle-level content-area teachers demonstrate evidence of adopting literacy strategies presented in professional development in their classrooms?

\section{Sample}

The study used a convenience sample of three English teachers, one mathematics teacher, three science teachers, and four social studies teachers $(N=11)$ all from the same middle school in central Pennsylvania. The school was in a suburban area and served a total of 739 students of which $4.60 \%$ were Asian, $9.07 \%$ were Black, $6.22 \%$ were Hispanic, $4.33 \%$ were multiracial, and $75.78 \%$ were White. Twenty-three percent were designated economically disadvantaged. Teacher participants had between 8 and 20 years of experience, and all but one held a master's degree in education. All were certified for secondary education in their content area (Smith, 2017).

Because the participants were selected through a convenience sample, several precautions were taken to eliminate bias. The interviews with each participant were taped to maintain the reliability and validity of the participants' responses and to eliminate bias during the transcription process. After transcribing each interview, participants received a copy of their transcripts for member-checking to ensure the participants' responses to the interview questions had been accurately captured and to eliminate bias. Participants had the opportunity to verify the accuracy of their transcript and correct any errors that might have been made. In addition, the participants could add needed clarifications to any statements that could have been misconstrued. Finally, an external audit was conducted by soliciting an overview of the study by someone not affiliated with the research to help identify the strong points, weak areas, and bias.

\section{Procedure}

During the 2014-2015 school year, the school district referenced in this study implemented a large-scale literacy initiative focused on performance tasks, close reading, vocabulary building, and reflective writing practices to be used across content areas. Initially, the professional development was delivered by an outside educational consulting company; however, due to negative response by teachers, the district chose to use a train-the-trainer model. The educational consulting company was retained to deliver training to smaller groups of teachers who then delivered the professional development to the rest of the district staff in small groups. The teachers who were chosen to initially deliver the training to their colleagues were designated as Cohort 1 and were focused on an overview of the literacy initiative. Subsequent cohorts of teachers volunteered or recruited by the district administration taught the other components of the initiative including close reading, performance tasks, vocabulary building, and reflective writing. The data for this study were collected during the 2015-2016 school year after initial trainings had been completed for all the components of the literacy initiative, and future trainings to continue the initiative were still being scheduled.

\section{Teacher interviews}

The semi-structured interviews took place with each participant at a convenient location and lasted from 25 to $55 \mathrm{~min}$. An interview protocol was prepared to guide the interviews based on the research questions and the theoretical underpinnings of the study (see Appendix). Clarifying and probing questions were added throughout the interview to ensure understanding of participants' meaning in their initial response and to allow them to further explain their views. Each interview was audio-taped and transcribed within 3 days of the 
interview to maintain the reliability and validity of the responses. Member-checking was also used to ensure that participants' responses were correctly captured.

Computer-assisted data analysis was conducted using Atlas.ti Version 7.5 for coding. First, the interviews were coded deductively (Kawulich, 2017), connecting participant statements to theoretical underpinnings identified for use in this study, including self-efficacy, constructivism, and andragogy. Then the interviews were analyzed inductively to identify themes that related to each of the research questions. Themes that emerged from the participant interviews were then triangulated with data collected from lesson plan review and classroom observations.

\section{Classroom observations}

Passive, nonparticipant classroom observations (Creswell, 2012) were conducted in each of the participants' classrooms to observe literacy strategy use. Descriptive field notes were taken during the classroom observations and each lesson was audio-recorded and transcribed. The transcribed observations were later coded in Atlas.ti in relation to teachers' use of literacy strategies, including vocabulary building, close reading strategies, and reflective writing. Educational resources were also collected, including texts used for instruction. During classroom observations, artifacts of student work that were displayed in the classroom were observed to determine whether students' use of literacy strategies was present. These observations aided in determining teachers' comfort with and use of literacy strategies that were taught in the professional development sessions.

\section{Lesson plan review}

Lesson plans were collected from each of the participating teachers for a 2-week period of their choice during the 2015-2016 school year. The plans were coded using the Atlas.ti program to identify the literacy strategies used by the content-area teachers.

\section{Results}

The interview data captured the teachers' beliefs and values about teaching reading and their capacity to implement literacy strategies in the content areas of English, math, social studies, and science. Themes that emerged from the data indicated the varied perspectives of the participants toward the role of literacy instructor. The data showed that teacher perception of the literacy initiative impacted their engagement in the ongoing literacy professional development. Although evidence of teacher compliance with the district initiative to implement literacy strategies was observed, there were both positive and negative teacher viewpoints toward the district expectations and professional development trainings. Table 1 shows themes as they relate to each research question, which are then described in the following sections. 


\begin{tabular}{lc}
\hline \multicolumn{1}{c}{ Research question } & Theme \\
\hline $\begin{array}{l}\text { 1: Does the current literacy professional } \\
\text { development engage teachers? }\end{array}$ & Delivery of professional development \\
& I'm interested if I like it \\
Where does it fit in my instruction? \\
$\begin{array}{l}\text { 2: How capable do middle-level content- area } \\
\text { teachers feel regarding teaching literacy to their } \\
\text { students following the professional } \\
\text { development? }\end{array}$ & Comfort level and ability to teach strategies \\
$\begin{array}{l}\text { 3: To what extent do teachers demonstrate evidence } \\
\text { of adopting literacy strategies presented in } \\
\text { professional development in their classrooms? }\end{array}$ & I'm want to do it my way \\
\end{tabular}

\section{Research Question 1: Does the Current Literacy Professional Development Engage Teachers?}

The study yielded multiple viewpoints regarding this question. Teacher involvement in one or more of the cohorts as trainers affected their views on the training provided. Several comments were made that showed engagement among the teachers. Participant 1 said, "I think we're learning some good strategies and once people get over the initial shock of this is really different ... it's good for our kids, and I feel it's making me a better teacher." Participant 8 suggested, “My go-to's at this point are all of the things that we learned during the professional development sessions. Those expected things from the close reading and the reflective writing. I use graphic organizers; the KWL charts, things like read-alouds.” Participant 11 stated,

I liked the delivery from the people that you teach with, not from these hired guns. The hired guns, that whole year was awful. Until they started the cohorts, I was tuned out. As a matter of fact, I was confused. And the vocabulary one was one of the earlier ones, it was like the second one, I was confused.

\section{Research Question 2: How Capable Do Middle-Level Content-Area Teachers Feel Regarding Teaching Literacy to Their Students Following the Professional Development?}

The interview questions and classroom observations provided insight into the level of teacher capability to teach literacy to their students. The following notations were made in the observation field notes.

- Participant 6 seems comfortable assisting with the activity.

- Participant 5 knows the story and appears to know the value of using the text to support the students' activity.

- Participant 5 shows knowledge of the literacy strategy and how to teach it to students.

- Participant 1 appeared calm and comfortable during this part of the instruction.

- Participant 8 supports students' drawing and connection to the vocabulary words.

- While drawing, Participant 3 is talking about the task with students at the table where teacher is sitting. Participant 3 is modeling what students should be doing. 
The classroom observations also provided a glimpse into the value teachers placed on time devoted to literacy instruction. All observations contained either vocabulary instruction, close reading, or reflective writing activities, all of which were taught in the literacy professional development session. As indicated by comments like the following, teachers admitted to not feeling competent in delivering some literacy components:

I am not a reading teacher, I'm not a literacy coach, and I'm not trained in that regard. I know how to read, I know how to guide students in reading, and I know how to kinda help them within the content. I don't know all the other strategies that could help them or how to help them with the content reading. So, in that regard, I don't think I am overly prepared to act . . . as a surrogate reading teacher in my classroom.

Participant 15 appeared to be more confident and said, "I am more conscious of, making sure the kids are reading, checking for understanding, introducing vocabulary, trying to find some articles that would give students background knowledge about something they are currently reading." The requirement to teach reflective writing was looked upon more favorably than the close reading or performance tasks as seen in this participant's response: "I like reflective writing. I don't have a problem incorporating that at all. You can do it, it's quick, easy, doesn't take a lot of time."

\section{Research Question 3: To What Extent Do Teachers Demonstrate Evidence of Adopting Literacy Strategies Presented in Professional Development in Their Classrooms?}

Numerous field notes included strategies observed in the classroom and identified in lesson plans in response to this research question. Teachers were observed using many literacy strategies in their classroom instruction. Lesson plans included the following strategies along with many others: 3-2-1 exit slips, the use of text evidence, questioning, Frayer models (Just read now, n.d.); think alouds (Wilhelm, 2008); turn and talks, close readings, graphic organizers, Socratic Seminars (Filkins, n.d.); and reflective writing (Fisher \& Frey, 2014; Sewell, 2014). Teachers described the impact of adopting literacy strategies in their classrooms. Participant 16 stated, "Oh, it's had a dramatic impact, specifically the close reading." Participant 16 added that lesson development and finding resources took a lot of time but saw their importance: "I work with other history teachers, and it was really important for us in our close reading to really hit the curriculum, not just be this extra thing 'Hey we did it. We can cross it off the list."”

All participants were willing to use the materials provided during the professional development sessions because they provided clear guidelines to follow. Participant 4 said, "I have all the information they have given us. They've showed us the studies how important it is." Another participant stated, "I go through that form that they make you go through" (Participant 6). However, some of the participants expressed skepticism that the program would have changed teaching practice without forced compliance: "Well if there was no expectation to do it, how many people would?” (Participant 3).

\section{Discussion}

Although the participants believed that literacy instruction across content areas was important and used literacy strategies in their classes following the literacy professional development, many still had a negative view of the professional development and lacked confidence in their ability to teach literacy skills. Many of the teachers saw value in teaching reflective writing and planning performance tasks within their curriculum; however, many teachers did not feel prepared to teach close reading with fidelity and negatively viewed the value in teaching close reading. They also expressed frustration that close reading took time away from the curriculum and that students were not receptive to the close reading lessons. Another challenge was the time and effort it took to find rigorous and relevant articles that related to the content. However, there were 
teachers who saw the value in teaching close reading and were concerned that other teachers were not complying with this expectation.

The finding regarding teachers' confidence in teaching some of the literacy skills could be explained by the principles of Bandura's self-efficacy theory that were not addressed when the professional development was planned. The program lacked a focus, as participants expressed that expectations were constantly changing, leading to confusion on what the expected methods were for bringing literacy strategies to the students. This along with the strict accountability measures seemed to lead to negative emotional responses, which have been shown to have a negative impact on self-efficacy (Bandura, 1977; Iorga et al., 2016). The participants also had no opportunities to attempt these practices and reflect on their use collaboratively, prior to the forced compliance component being instituted. Because self-efficacy is impacted by the previous success of using skills (Zimmerman, 1995), not having these opportunities to reflect and collaborate may have affected the teachers' self-efficacy

Previous research has supported these findings. In a related study, Varghese and colleagues (2016) found a positive, significant connection between the teachers' improvement in classroom management efficacy and the literacy skill improvement of their students. Thus, teachers' feelings of self-efficacy matter in improving students' literacy achievement (Varghese et al., 2016). Further, Kaufman et al., (2016) found that despite the many teachers who have participated in professional development geared toward implementing the Common Core State Standards, many teachers have not made any substantial changes in literacy teaching.

The theoretical framework also supported the findings. Despite negative responses regarding the professional development, there were several positive outcomes, including perceived growth relative to the participants' previous understanding of literacy instruction, increased use of literacy strategies, and ownership taken by those involved in the cohort model. All participants were certified within their content areas and were tasked with adding a level of expertise to their current knowledge, which they did by adding strategies to their instructional methods. Thus, Bruner's (1960) constructivist theory was evident in that learners built meaning based on their previous knowledge.

There was also evidence of Knowles's theory of andragogy setting the climate for adult learning based on acceptance and respect. The participants who took part in the cohort training and delivery of training had a more favorable impression of the professional development and components of the literacy initiative than those who were not involved in any of the cohorts. This may be due to the cohort participants' greater voice and involvement in the literacy initiative. This model for cohort members also worked more like a coaching model for professional development, allowing teachers to collaborate, try out the new literacy strategies, and reflect upon their practice as they were involved in the planning of the professional development for their colleagues (Dillon et al., 2015; Graham et al., 2017; Wardrip et al., 2015). If a coaching model for all teachers had been employed, the professional development might have had a more positive reception. Teacher selfefficacy is heightened, and perspectives and practices can be changed as a result of continuous job-embedded professional development focused on teaching content literacy practices (Dixon et al., 2014; Dunn, Airola, \& Garrison, 2013; Dunn, Airola, Lo, \& Garrison, 2013; Graham et al., 2017).

The participants suggested improvements to the program so that it could have better met their needs. These are the suggestions relayed during the interview process.

- Common planning period or collaboration time during the day-per grade, as well as within grades, to talk and share expertise

- Eliminate close reading mandate forced into all content areas several times per year

- Additional training on literacy strategies in plain language

- If close reading must be done, help finding rigorous, relevant articles that relate to subject matter 
- Strategies for helping struggling readers

- Flexibility and respect for teacher instructional decisions

- Team time with all team members present

- Time to collaborate more, maybe during faculty meetings or department meetings

- Chance to observe other teachers

The most common need expressed by the participants was time to collaborate within a grade level and across grades both for planning and to share expertise among colleagues. Research shows that although there are benefits of collaborative planning, many teachers struggle to find time and acquire administrative support (Patterson et al., 2017). The participants also wanted periodic refresher courses to help them remember what was taught in professional development courses. Educational leaders and facilitators of professional development can benefit by listening to the challenges and interests of teachers (Bates \& Morgan, 2018). Professional development offers the opportunity to train and coach teachers through the implementation of new initiatives, including those related to literacy instruction. However, the method used to deliver the professional development can impact how teachers perceive the professional development program and could affect their likelihood to embrace the training and alter their instruction as a result (Smith, 2017).

\section{Conclusion}

The purpose of this study was to examine middle-level content-area teachers' perspectives on a professional development initiative intended to promote literacy through the integration of literacy strategies in contentarea classrooms. The research focused on these teachers' perspectives on the delivery of the literacy professional development as well as their resulting strengths and weaknesses in this area. Teachers also provided feedback into what supports would help them to feel more successful in literacy integration. Researchers agree that more studies are needed to examine the connection between teachers' values and administrators' values toward literacy instruction (Martin et al., 2018). It was found that teachers valued literacy and felt literacy instruction was important in their content-area. It was also found that although the literacy professional development led to the incorporation of the literacy strategies into their instruction, their self-efficacy remained low in this area. Perceived lack of vision and a forced compliance method were the components that had the most negative feedback from participants. These data can be valuable to school administrators who desire successful implementation of school professional development initiatives that require teacher endorsement. Although there is research that confirms the need for professional development that incorporates collaboration, there is room for further research in the area of collaborative professional development models and the most beneficial way to integrate literacy strategies across content areas.

\section{Implications}

The findings and conclusion presented here have implications for future practice when implementing new initiatives in middle-level schools. The results provide recommendations for administrators and professional development facilitators of middle-level schools to consider, prior to implementing new school initiatives. Arrangements for collaboration coupled with teacher support should be part of the initiation of new strategies (Richman et al., 2019). Additionally, Greenleaf and colleagues (2018) found that without additional interventions, teachers have difficulty integrating literacy into content instruction. Another study has shown that teachers feel their work is enhanced when they are permitted to collaborate with other educators to learn new strategies and create lesson plans (Richman et al., 2019). Allowing teachers time to collaborate as a part of literacy professional development may address the finding of the current study that teachers lacked confidence in their ability to implement literacy strategies in their content-area classrooms and felt disengaged during the professional development sessions. 
Additionally, it has been found that teachers' engagement is increased when teachers feel secure and empowered to share how they feel about the problems of their practice; teachers' voices need to be heard (Bates \& Morgan, 2018). While teachers in the current study were frustrated by a strict compliance model through the implementation process, teacher participants in a study conducted by Richman and colleagues (2019) responded overwhelmingly that they appreciated the opportunity to work with educators from surrounding schools and collaborate with others to learn new strategies and create new learning experiences. These teachers also received additional training over time and were given support to integrate literacy standards into their lessons (Richman et al., 2019). The current study and others have demonstrated that teachers value professional development and make efforts to implement new strategies into their instruction; however, it is imperative that the training meet teacher's needs and consider adult learning styles (Martin et al., 2018).

\section{References}

Ajayi, L. (2011). Preservice teachers' knowledge, attitudes, and perception of their preparation to teach multiliteracies/multimodality. Teacher Educator, 46(1), 6-31. https://doi.org/10.1080/08878730.2010.488279

Akin, G. (2014). The term of andragogy and the difference between andragogy and pedagogy. Journal of Faculty of Educational Sciences, 47(1), 279-300.

Arab, M., Ghavami, B., Lakeh, M. A., Esmaeilpoor, S., Yaghmaie, M., \& Hosseini-Zijoud, S. (2015). Learning theory: Narrative review. International Journal of Medical Reviews, 2(3), 291-295.

Bandura, A. (1977). Self-efficacy: Toward a unifying theory of behavioral change. Psychological Review, 84(2), 191-215.

Bates, C. C., \& Morgan, D. N. (2018). Literacy leadership: The importance of soft skills. Literacy Coaching and Professional Development, 72(3), 412-415. https://doi.org/10.1002/trtr.1755

Bullock, D. (2011). Learner self-assessment: An investigation into teachers' beliefs. English Language Teachers Journal, 65(2), 114-125.

Bruner, J. (1960). The process of education. Harvard University Press.

Butler, D. L., Schnellert, L., \& MacNeil, K. (2015). Collaborative inquiry and distributed agency in educational change: A case study of a multi-level community of inquiry. Journal of Educational Change, 16, 1-26. https://doi.org/10.1007/s10833-014-9227-z

Carney, M., \& Indrisano, R. (2013). Disciplinary literacy and pedagogical content knowledge. Journal of Education, 193(3), 39-46.

Clary, D. M., Styslinger, M. E., \& Oglan, V. A. (2012). Literacy learning communities in partnership. SchoolUniversity Partnerships, 5(1), 28-39.

Cohen, S. (2015). Coteaching: A success story. Teacher Librarian, 42(5), 8-11.

Creswell, J. W. (2012). Educational research: Planning, conducting, and evaluating quantitative and qualitative research (Laureate custom ed.). Pearson Education.

Cronin, M. K. (2014). The common core of literacy and literature. English Journal, 103(4), 46-52.

Culatta, R. (2013). Instructional design: Constructivist theory (Jerome Bruner). http://www.instructionaldesign.org/theories/constructivist.html 
Daisey, P. (2012). The promise of secondary content area literacy field experiences. Literacy Research and Instruction, 51(3), 214-232. https://doi.org/10.1080/19388071.2011.556211

Dillon, P., Erkens, C., Sanna, D., \& Savastano, L. F. (2015, June). Crowdlearning: 8 Districts pool resources to focus on assessment literacy. JSD: The Learning Forward Journal, 36(3), 28-31.

Dixon, F. A., Yssel, N., McConnell, J. M., \& Hardin, T. (2014). Differentiated instruction, professional development, and teacher efficacy. Journal for the Education of the Gifted, 37(2), 111-127.

Dunn, K. E., Airola, D. T., \& Garrison, M. (2013). Concerns, knowledge, and efficacy: An application of the teacher change model to data driven decision-making professional development. Creative Education, 4(10), 673-682.

Dunn, K. E., Airola, D. T., Lo, W., \& Garrison, M. (2013). Becoming data driven: The influence of teachers' sense of efficacy on concerns related to data-driven decision making. Journal of Experimental Education, 81(2), 222-241. https://doi.org/41.1080.00220973.2012.699899

Falk-Ross, F., \& Evans, B. (2014). Word games: Content area teachers' use of vocabulary strategies to build diverse students' reading competencies. Language and Literacy Spectrum, 24(1), 84-100.

Filkins, S. (n.d.). Strategy guide: Socratic seminars. http://www.readwritethink.org/professionaldevelopment/strategy-guides/socratic-seminars-30600.html

Fisher, D., \& Frey, N. (2014). Content area vocabulary learning. The Reading Teacher, 67(8), 594-599. https://doi.org/10.1002/trtr.1258

Goldring, E. B., Preston, C., \& Huff, J. (2012). Conceptualizing and evaluating professional development for school leaders. Planning and Changing. 43(3/4), 223-242.

Graham, A., Kerkhoff, S., \& Spires, H. (2017). Disciplinary literacy in the middle school: Exploring pedagogical tensions. Middle Grades Research Journal, 11(1), 63-83.

Green, J. D., Gonzalez, E. M., Lopez-Velasquez, A. M., \& Howard, E. R. (2013). Hands-on professional development: Middle school teachers' experiences with a curriculum intervention research project. Middle School Journal, 45(2), 27-32.

Greenleaf, C., Litman, C., \& Marple, S. (2018). The impact of inquiry-based professional development on teachers' capacity to integrate literacy instruction in secondary subject areas. Teaching and Teacher Education, 71, 228-240.

Guthrie, J. T., \& Klauda, S. L. (2012). Making textbook reading meaningful. Educational Leadership, 69(6), 64-68.

Hall-Kenyon, K. M., \& Smith, L. K. (2013). Negotiating a shared definition of curriculum integration: A selfstudy of two teacher educators from different disciplines. Teacher Education Quarterly, 4O(2), 89108.

Henschke, J. A. (2008). Reflections on the experiences of learning with Dr. Malcolm Shepherd Knowles. New Horizons in Adult Education and Human Resource Development, 22(3/4), 44-52. http://education.fiu.edu/newhorizons

Hurst, B., \& Pearman, C. J. (2013). "Teach reading? But I'm not a reading teacher!" Critical Questions in Education, 4(3), 225-234.

International Reading Association Common Core State Standards Committee. (2012). Literacy implementation guidance for the ELA Common Core State Standards. http://www.reading.org/Libraries/associationdocuments/ira ccss guidelines.pdf 
Iorga, M., Diaconu, L., Soponaru, C., \& Anton-Paduraru, D. (2016). The influence of self-efficacy on the emotional work of teachers. Romanian Journal of Experimental Applied Psychology, 7(1), 717-721.

Jones, W. M., \& Dexter, S. (2014). How teachers learn: The roles of formal, informal, and independent learning. Education Technical Research Development, 62(1), 367-384. https://doi.org/10.1007/s11423-014-9337-6

Jordan, J., \& Kaplan, R. (2014). Intending to meet: The truth about collaboration. English Journal, 103(3), 28-33.

Just Read Now. (n.d.). Frayer model. http://www.justreadnow.com/strategies/frayer.htm

Kaufman, J. H., Hamilton, L., Stecher, B. M., Naftel, S., Robbins, M., Thompson, L. E., . .Opfer, V. D. (2016). What supports do teachers need to help students meet common core state standards for English language arts and literacy? https://www.rand.org/pubs/research reports/RR1374-1.html

Khanal, P. (2014). Making virtual learning interactive and meaningful: Implications of constructivism for adult students. International Journal of Research Studies in Education, 3(1), 91-102.

Kawulich, B. (2017). Coding and analyzing qualitative data. In D. Wyse, N. Selwyn, \& E. Smith (Eds.), The BERA/SAGE handbook of educational research (Vol. 2, pp. 769-790). London, United Kingdom: Sage. https://doi.org/10.4135/9781473983953.n39

Martin, C., Polly, D., Mraz, M., \& Algozzine, R. (2018). Teacher perspectives on literacy and mathematics professional development. Issues in Teacher Education, 27(1), 94-104.

Matherson, L., \& Windle, T. M. (2017). What do teachers want from their professional development? Four emerging themes. Delta Kappa Gamma Bulletin, 83(3), 28-32.

Merriam, S. B. (2001). Andragogy and self-directed learning: Pillars of adult learning theory. New Directions for Adult and Continuing Education, 89(1), 3-13.

Moreillon, J. (2016). Building your personal learning network (pln): 21st Century school librarians seek selfregulated professional development online. Knowledge Quest, 44(3), 65-69.

Moreillon, J., \& Ballard, S. D. (2012). Coteaching: A pathway to leadership. Knowledge Quest, 4O(4), 6-9.

Murphy, S. (2015). “How do we teach them to read if they can't pay attention?”: Change in literacy teaching practice through collaborative learning. Language and Literacy, 17(1), 83-105.

National Governors Association Center for Best Practices, Council of Chief State School Officers. (2010). Common Core State Standards. http://www.corestandards.org/about-the-standards/brandingguidelines/

Ning, M., Shuang, X., \& Jia-Yuan, D. (2018). A peer coaching-based professional development approach to improving the learning participation and learning design skills of in-service teachers. Journal of Educational Technology \& Society, 21(2), 291-304.

Orr, A. M., Kukner, J. M., \& Timmons, D. J. (2014). Fostering literacy practices in secondary science and mathematics courses: Pre-service teachers' pedagogical content knowledge. Language and Literacy, 16(1), 91-110.

Park, J. Y. (2013). All the ways of reading literature: Preservice English teachers' perspectives on disciplinary literacy. English Education, 45(4), 361-384.

Parsons, A. W., Richey, L. N., Parsons, S. A., \& Dodman, S. L. (2013). How do teachers change their practice? Case studies of two teachers in a literacy professional development initiative. Yearbook of the Association of Literacy Educators and Researchers, 35, 127-141. 
Patterson, N., Weaver, J., Fletcher, J., Connor, B., Thomas, A., \& Ross, C. (2017). Leveraging literacies through collaborative, source-based planning and teaching in social studies and language arts. Journal of Adolescent \& Adult Literacy, 61(5), 523-532. https://doi.org/10.1002/jaal.712

Reed, D. K. (2009). A synthesis of professional development on the implementation of literacy strategies for middle school content area teachers. Research in Middle Level Education Online, 32(10), 1-12.

Richman, L., Haines, S., \& Fello, S. (2019). Collaborative professional development focused on promoting effective implementation of the next generation science standards. Science Education International, 3o(3), 200-208. https://doi.org/10.33828/sei.v30.i3.6

Sewell, W. (2013). Preservice teachers' literacy strategies preferences: Results of a two-year study of content area literacy students. Journal of Content Area Reading, 1O(1), 121-149.

Smith, O. L. (2017). Content area teacher perspectives on integrating literacy strategies (Doctoral dissertation). https://scholarworks.waldenu.edu/dissertations/3837/

Summers, E. G. (1977). Instruments for assessing reading attitudes: A review of research and bibliography. Journal of Reading Behavior, 9(2), 137-165. https://doi.org/10.1080/10862967709547215

Varghese, C., Garwood, J., Bratsch-Hines, M., \& Vernon-Feagans, L. (2016). Exploring magnitude of change in teacher efficacy and implications for students' literacy growth. Teaching and Teacher Education, $55,228-239$.

Wardrip, P. S., Gomez, L. M., \& Gomez, K. (2015). We modify each other's lessons: The role of literacy work circles in developing professional community. Teacher Development, 19(4), 445-460.

Warren-Kring, B. Z., \& Warren, G. A. (2013). Changing the attitudes of pre-service teachers toward content literacy strategies. Reading Improvement, 5o(2), 75-82.

Wei, R. C., Darling-Hammond, L., Andree, A., Richardson, N., \& Orphanos, S. (2009). Professional learning in the learning profession: A status report on teacher development in the United States and abroad. National Staff Development Council. https://edpolicy.stanford.edu/sites/default/files/publications/professional-learning-learningprofession-status-report-teacher-development-us-and-abroad.pdf

Wilhelm, J. D. (2008). National writing project. navigating meaning: Using think-alouds to help readers monitor comprehension. http://www.nwp.org/cs/public/print/resource/495

Woods, K. (2014). A footprint for collaboration. Teacher Librarian, 42(1), 13-17

Zimmerman, B. (1995). Self-efficacy and educational development. In A. Bandura (Ed.), Self-efficacy in changing societies (pp. 201-231). Cambridge University Press.

\section{[Appendix follows]}




\section{Appendix}

\section{Interview Questions}

1. How long have you been teaching?

2. What is your area of certification? Do you hold any other degrees?

3. What formal literacy training have you experienced?

4. What do you currently believe and/or value about reading and reading instruction?

5. How would you describe the impact of the expectation for all teachers to teach literacy strategies, specifically close reading and reflective writing?

6. What are your thoughts about the expectation to integrate literacy strategies within your content instruction?

7. What literacy strategies do you use in your classroom?

8. How do you approach planning and preparing to teach close reading lessons?

9. How do you approach planning and preparing to teach reflective writing lessons?

10. Describe the types of literacy training you have experienced.

11. What do you see as your strengths in the area of teaching reading?

12. What do you see as your areas of weakness in the teaching reading?

13. How prepared do you feel you are to teach the expected literacy strategies to your students.

14. How often do you use literacy strategies in your classroom?

15. How effective do you feel you are at teaching close reading lessons?

16. How effective do you feel you are at teaching reflective writing lessons?

17. How likely are you to seek the help of a colleague in preparing a literacy lesson?

18. How likely are you to seek the help of a reading specialist in preparing a literacy lesson?

19. How much time would you say it takes you to prepare a close reading lesson?

20. How much time would you say it takes you to prepare a reflective writing lesson?

21. How much time would you say it takes you to prepare a literacy performance task?

22. Have you changed your perspective about teaching literacy since the RRR initiative began?

23. What challenges or concerns do you have about teaching literacy? How do you think these can be resolved?

24. Is there anything else you would like to tell me?

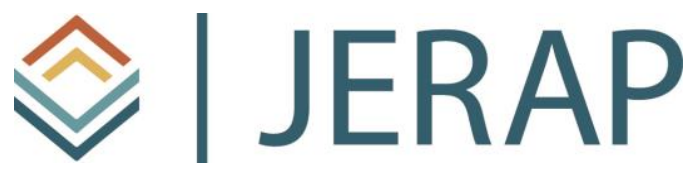

The Journal of Educational Research and Practice is a peerreviewed journal that provides a forum for studies and dialogue about developments and change in the field of education and learning. The journal includes research and related content that examine current relevant educational issues and processes. The aim is to provide readers with knowledge and with strategies to use that knowledge in educational or learning environments. JERAP focuses on education at all levels and in any setting, and includes peer-reviewed research reports, commentaries, book reviews, interviews of prominent individuals, and reports about educational practice. The journal is sponsored by the Richard W. Riley College of Education and Leadership at Walden University, and publication in JERAP is always free to authors and readers. 